\title{
RE-IMAGINING A CULTURE OF JUSTIFICATION THROUGH TRANSFORMATIVE CONSTITUTIONALISM AND THE PHILOSOPHY OF UBUNTU
}

\author{
by Ofentse T Kgabo*
}

\section{Introduction}

Twenty years after the adoption of the Constitution, ${ }^{1}$ it is fitting to reflect on the development of our constitutional democracy. In light of purposive interpretation of statutes, ${ }^{2}$ one is required to question the intention of the drafters of the Constitution, to consider the context which necessitated its promulgation and to contemplate whether effect has been given to the content of the rights and freedoms contained therein. ${ }^{3}$ Ever-increasing inequalities in our society have prompted a return to the promise of 'transformative constitutionalism'. ${ }^{4}$ Klare defines transformative constitutionalism as a 'long-term project of constitutional enactment, interpretation, and enforcement' committed to transforming political and social institutions 'in a democratic, participatory, and egalitarian direction.' 5 The main problem which will be evaluated in this article is identified by Klare as the 'formalistic legal culture' which persists in all spheres of our socio-political and economic life. Several questions are asked; the first being whether transformative constitutionalism is able to overcome this pervading formalistic legal culture inculcated in our judicial system to advance social transformation and drive the progressive realisation of socioeconomic rights.

In so doing, a further question addresses whether the doctrine of separation of powers has been eroded by the flurry of political matters and executive functions which have increasingly come under question before our courts. Courts are sometimes required to remove the veil to derive new patterns of legal thought in order to strengthen constitutional dialogue between state institutions. However, it can be

Final year LLB, University of Pretoria.

Constitution of the Republic of South Africa, 1996.

19952 SACR 1 (CC) para 9; 19951 SACR 568 (CC).

3 The Bill of Rights safeguards the individual rights and freedoms of all people who reside within the territory of the Republic. However, these rights and freedoms are not absolute and are subject to limitation in terms of section 36 (often referred to as the 'limitation clause').

4 K Klare 'Legal culture and transformative constitutionalism' (1998) 14 South African Journal on Human Rights 146.

$5 \quad$ Klare (n 4 above) 150. 
argued that many of the matters which come before our courts are burdensome and may be negotiated better through the effective and purposive implementation of policy objectives.

A third question deals with the legacy of colonialism and apartheid, which will be addressing the marginalisation of indigenous law as a result of legal formalism which continues to suppress African values in favour of long-standing common law principles. It seems clear that at the heart of these problems is the formal legal culture which continues to pervade our courtrooms and chambers. In keeping with the transformative aspirations of our Constitution, this article seeks to illustrate the need for a distinctly African jurisprudence (specifically Ubuntu) which takes cognisance of the need for transformative policies to be implemented to bring about the restoration of the dignity of our indigenous black people. ${ }^{6}$

\subsection{From authoritarianism to a culture of justification}

As engaged legal scholars, we ought to ask such questions as 'what is (the) law?' and even more so, 'what ought (the) law to be?' Boyd White contends that the law is an 'inherently unstable structure of thought and expression, built upon a distinct set of dynamic and dialogic tensions. ${ }^{7}$ These tensions present themselves in the form of contestation between the realisation of liberty on the one hand, and the exercise of legal constraint on the other. ${ }^{8}$ Boyd White views the law as a mechanism for the reinvention of old ideals and their realignment with the lived experiences of modern society. He further suggests that law has the ability to appease its own conscience by acknowledging historical customs, while addressing the demands of social justice and transformation. The law carries immense gravitas to drive national and political imperatives thus it is futile to attempt to espouse a distinction between the realm of politics and that of law. In order to make significant strides in the achievement of transformation, the courts and the judges who preside over them ought to persist in their engagement of the merits of law when formulating legal judgments. In a constitutional democracy, judicial adjudication can no longer be considered a mere mechanical function as this is inconsistent with the language of generous and purposive interpretation. ${ }^{9}$ Harkening back to the words of Mureinik, ${ }^{10}$ it is imperative that all exercises of public power be justified in order to

6 The terms 'black' and 'African' are used interchangeably throughout this paper to denote people of African descent.

7 J Boyd White 'Justice in tension: An expression of law and the legal mind' (2012) 9 No Foundations 1.

$8 \quad$ Klare (n 4 above) 149.

9 Zuma (n 2 above) para 14.

10 E Mureinik 'A bridge to where? Introducing the interim Bill of Rights' (1994) 10 South African Journal on Human Rights 33. 
satisfy the founding constitutional values of accountability, responsiveness and transparency as expressed in section 1 (d) of the Constitution. This notion is well-articulated in the advent of transformative constitutionalism. This article will examine the existing legal culture and legal traditions in South Africa and postulate whether transformative constitutionalism goes far enough to facilitate large-scale social and political transformation.

Subsequent to the promulgation of the Constitution, commentary and critique which included the conception of transformative constitutionalism followed almost immediately. Prior to this, the nature and character of the South African Constitution was widely under dispute. Based on a reading of the preamble, it is unambiguous that the Constitution represents a conscientious pursuit of restoration and social justice which is buttressed on the recognition of fundamental human rights and equality before the law; a commitment to the rule of law as the basis for a democratic and open society; a commitment to the improvement of the basic living conditions of all citizens and most importantly, the democratisation of our country and reconciliation of all its people. This undertaking is fraught with diverging conflicts between the changes and advancements which are necessary to achieve transformation and the certainty of legal discourse in adjudication. ${ }^{11}$ The Postamble to the interim Constitution ${ }^{12}$ makes reference to 'a historic bridge between the past of a deeply divided society [...] and a future founded on the recognition of human rights. 13 The late Etienne Mureinik builds on this analogy of a 'historic bridge' to assert that what the bridge represents is a break away from a history of authoritarianism under the apartheid regime, to a 'culture of justification [...] in which every exercise of power is expected to be justified.' 14 This transition into a new democratic order recalls a past steeped in coercion. At the same time, it also articulates the promise of a future where 'the leadership given by government rests on the cogency of the case offered in defence of its decisions, [and] not the fear inspired by the force at its command.' 15

Klare's advancement of transformative constitutionalism as a substantive theory of constitutional enactment centres itself around the enforcement and interpretation of law to transform the historical link between 'political and social institutions, and [ensuing] power relationships in a democratic, participatory and egalitarian direction." 16 This entails an undertaking to induce 'large-scale social

11 AJ van der Walt 'Legal history, legal culture and transformation in a Constitutional democracy' (2006) 12 Fundamina 4.

12 Constitution of the Republic of South Africa Act 200 of 1993.

13 Mureinik (n 10 above) 31.

14 Mureinik (n 10 above) 32.

15 As above.

16 Klare (n 4 above) 150. 
change through nonviolent political processes grounded in law.' ${ }^{17}$ In a context where legal positivism has had devastating consequences for the lives and social welfare of indigenous black people, the language of law is a powerful source of intervention to drive an overarching enterprise dedicated to the advancement of human dignity, equality and freedom. After four hundred years of British colonial rule, the National Party government systematically passed laws which fashioned a blueprint for the sophisticated architecture of institutionalised racism. The system of parliamentary sovereignty which existed at the time in question did not represent the will of the people, but was nonetheless used to enact laws that would prescribe the conditions in which indigenous African people led their daily lives. It is this prostitution of law which ultimately leads to the perversion of state for political ends. It is due in part to these very injustices that we now live in a democratic society built on the principles of Constitutional supremacy contained in the founding provisions. ${ }^{18}$

\subsection{Transformative constitutionalism as ideology}

The late Chief Justice Langa was of the opinion that the objective of transformation (and by extension, a transformative Constitution) is the realisation of 'a truly equal society.' 19 Even after the achievement of equal access to resources and basic services, transformation remains a 'permanent ideal' through which we ought to view the world. ${ }^{20}$ This ideal or perspective, he contends, "creates a space in which dialogue and contestation are truly possible [...] and in which change is unpredictable but the idea of change is constant. 21 There is something beautiful about this particular expression of transformative constitutionalism, as it reinforces the ultimate vision of a Constitution that is 'transformative, rather than [...] transitional. ${ }^{22}$ In re-imagining what a truly equal society might look like, it is fundamental to conceive the changes which must be made. It is also crucial to acknowledge (albeit hesitantly so) that equality is an ideal which we might possibly never achieve.

Albertyn and Goldblatt have noted that although there has been widespread consensus on the challenge of transformation underlying the Constitution, ${ }^{23}$ several readings of the Constitution are

17 As above.

18 Sec 2 of the Constitution, 1996.

19 P Langa 'Transformative constitutionalism' (2006) 3 Stellenbosch Law Review 354

20 As above.

21 Langa (n 19 above) 354

22 As above.

23 C Albertyn \& B Goldblatt 'Facing the challenge of transformation: Difficulties in the development of an indigenous jurisprudence of equality' (1998) 14 South African Journal on Human Rights 249. 
plausible. ${ }^{24}$ However, the key focus and mandate of our Constitution is the restoration of our society through the 'redistribution of power and resources along egalitarian lines. 25 Due to the many complexities at play, the redistribution of resources is an arduous task. The segregation along race, gender and class lines in South Africa is systemic throughout social and political institutions. ${ }^{26}$ An insidious relationship is evident from the manner in which law and politics relate to one another. Unjust political determinations can easily find legitimacy through law. Thus, as a necessary precaution, one should always be circumspect of the responsibility placed on those who develop the laws of South Africa.

\subsection{Obfuscation of substantive reasoning in a formal legal culture}

The Constitution functions as a time capsule by preserving memory through the overarching emphasis on dignity and equality. An insightful discussion on the distinguishing factors of the South African Constitution would be incomplete without mention of its archival role. ${ }^{27}$ When one begins to view the Constitution through an archival lens, one becomes more responsive in deducing the cautionary tales contained therein. The wording of the Constitution is heavily loaded in places, requiring one to tease out the intention of those who drafted it. The framing of founding provisions is unrepentant in its recollection of the past. ${ }^{28}$ This nuanced recollection fossilises South Africa's ghastly history but is not intended to confine one to that particular moment in history. ${ }^{29}$ The past presents itself as a sharp mirror, scrutinising past moral failings and magnifying the call for the achievement of substantive equality. ${ }^{30}$ In this way, the Constitution leverages South Africa's collective memory to cultivate fertile ground for participatory and responsive democracy. ${ }^{31}$

Scrutiny of the legal culture which permeates the corridors of courtrooms suggests that the transformation of our laws (or at the very least, law-making processes) has not significantly translated into the reconstitution of judicial method or adjudication. Klare makes the descriptive point that even on the back of a Constitution which

I will discuss this in greater detail at a later stage. This discussion takes place in reference to Klare's assessment that a 'postliberal' reading of the Constitution is the most plausible, if not the only plausible one.

25 Albertyn \& Goldblatt (n 22 above) 249.

26 As above.

27 D Cornell \& K Van Marle ‘Exploring Ubuntu: Tentative reflections' (2005) 5 African Human Rights Journal 198.

28 The Preamble to the Constitution 'recognise[s] the injustices of our past; [and] honour[s] those who suffered for justice and freedom in our land ...'

29 Klare (n 4 above) 155.

30 Sec 9 of the Constitution, 1996.

31 Klare (n 4 above) 155. 
actively mandates social transformation; the role of participants in a pervading legal culture is what ultimately determines the rules of engagement. ${ }^{32}$ In this sense, legal actors are complicit in the survival of the formal legal culture within which they find themselves constrained. Klare further suggests that the character of our legal culture and education need to be transformed in order to bring them in line with the values espoused in the Constitution. ${ }^{33}$ Though this disconnect seems obvious to Klare, Froneman J offers a diverging view which I believe is closer to the truth. ${ }^{34}$ Froneman $\mathrm{J}$ differs with the idea that legal actors actively observe the manifestation of formal reasoning in their work and proposes a self-awareness of the means through which conservatism in legal culture shapes professional sensibilities. ${ }^{35}$ Once all practitioners in the legal profession have taken it upon themselves to understand the reasons for which formal reasoning is employed, then it would simply be dishonest to continue to take refuge in a position of ignorance.

On one level, Klare is correct in asserting that legal practitioners who find themselves in a specified legal culture are trained in a particular manner to identify what constitutes a persuasive argument or method of adjudication and what does not. ${ }^{36}$ On another level, legal education cannot take credit entirely for orienting perceptions on solving legal problems. If one relies on 'cultural coding' to determine the manner in which legal problems and questions are framed, ${ }^{37}$ then this hinders the substantive development of law. Uneasiness abounds from certain corners within the legal profession when one invokes the necessity of a substantive formulation of law because a value-based approach is implied. Klare rightly points out that the supposed neutrality of formal law is a fiction because consequentially, a judge's personal beliefs and convictions can never fully be filtered out of the interpretive process. ${ }^{38}$ The narrative of an individual's daily life is centralised to his or her own experiences, therefore the point of view taken by a judge in their exercise of adjudication is uniquely their own. This unique perception or viewpoint, however, should not preclude judges from appreciating constructs of reason outside of their own. The contention here is that what distinguishes the work of judges is the skill they have acquired in striking a balance between applying existing formal rules and employing their imagination to innovate novel solutions to indistinct Stellenbosch Law Review 3

Froneman (n 33 above) 5.

Klare (n 4 above) 167.

Klare (n 4 above) 168. Klare (n 4 above) 163. 
questions of law. Therefore the trade of a judge involves a weighing up between purposive imagination and legal constraint. ${ }^{39}$

The common fear when it comes to a substantive vision of law is the space judges are given to impress their personal values and convictions in the exercise of their work. On the contrary, when one strips down the content of a formal rule, it is unavoidable to conceive the circumstances which existed or the intended outcome which warranted the formulation of that rule in the first place. ${ }^{40}$ At an initial level, justification for formal rules takes place in the lawmaking process. The framing of a particular formal rule cannot and does not take place within a vacuum because the "justification for the rule and what its likely consequences may be' motivates the formulation thereof. ${ }^{41}$ Thus the formulation of a formal rule simply "incorporate[s] those substantive reasons in its content. ${ }^{42}$ Froneman $\mathrm{J}$ cautions against this conceptualisation of law because when one devises formal rules which are substantively above reproach, law is given a life of its own and individuals are absolved of the decisions they implicitly make. ${ }^{43}$

To drive home this argument, advocacy for a substantive vision of law does not imply that 'anything goes' or that substantive reasoning allows us to imbue whatever textual meaning we so wish. ${ }^{44}$ Conversely, the point at which the legal materials before us become constrained in their meaning and our own legal interpretation proceeds, cannot be objectively determined. ${ }^{45}$ Law must be certain and determinable to some extent, but must also remain malleable enough to foster an environment in which to achieve its purpose. On the notion of legal subsidiarity (which is interpreted for present purposes to construe the hierarchy of sources of law), Klare accepts the proposition tendered by Van der Walt. ${ }^{46}$ The challenge from Van der Walt, lies in becoming "comfortable with gaps [in our law] rather than seeking refuge in supposedly stable and all-inclusive rules[...] because gaps open space for conversation, diversity, dissent, contestation, and judgment. ${ }^{47}$

39 Klare (n 4 above) 160.

40 Froneman (n 33 above) 6.

41 As above.

42 As above.

43 As above.

44 Klare (n 4 above) 160.

45 As above.

46 K Klare 'Legal subsidiarity \& constitutional rights: A reply to AJ van der Walt' (2008) 1 Constitutional Court Review 129.

47 Klare (n 4 above) 130. 


\section{Judicial reasoning and the exercise of public power}

All exercises of public power must comprise the rational exercise of that power. Insofar as the judicial authority of the Republic is vested in the courts, ${ }^{48}$ it is within their functional area of competence to institute judicial review proceedings of policy or conduct which is not in line with the spirit, purport and objects of the Constitution. I will address the role of courts (and especially that of the apex court, the Constitutional Court) to drive the transformative design ${ }^{49}$ of the Constitution. In line with this approach, arguments for a closer 'constitutional dialogue, 50 follow in fostering a culture of justification.

At this point in this discussion, it is important to note the operation of the doctrine of separation of powers, ${ }^{51}$ which must be inferred from the structure of the provisions in our Constitution. ${ }^{52}$ In addition to those provisions which establish the authority vested in various state organs, section $41(1)(e)$ explicitly provides that 'all organs of state within each sphere' must respect the constitutional status, powers and functions of government. Further, organs of state may 'not assume any power or function except those conferred on them in terms of the Constitution'. ${ }^{53}$ These provisions establish and give content to the doctrine of separation of powers. ${ }^{54} \mathrm{An}$ acknowledgement of the operation of the separation of powers is crucial to this discussion as this principle informs one aspect of the rational exercise of public power and necessitates the inclusion of checks and balances. In $S \vee$ Dodo, ${ }^{55}$ the Court emphasised that the principle of separation of powers as envisioned in our Constitution: ${ }^{56}$

... embodies a system of checks and balances designed to prevent an overconcentration of power in any one arm of government; it anticipates the necessary or unavoidable intrusion of one branch on the terrain of another; this engenders interaction, but does so in a way which avoids diffusing power so completely that government is unable to take timely measures in the public interest.

48 Sec 165(1) of the Constitution, 1996.

49 D Moseneke 'The fourth Bram Fischer memorial lecture: transformative adjudication' (2006) 18 South African Journal on Human Rights 309.

50 S Ngcobo 'South Africa's transformative Constitution: Towards an appropriate doctrine of separation of powers' (2011) 1 Stellenbosch Law Review 3739.

$51 \mathrm{~K}$ McLean Constitutional deference, courts and socio-economic rights in South Africa (2009) 105.

52 This separation of power is evidenced by the differentiation between the powers vested in the executive, the legislature and the judiciary (established in secs $85(1), 43$ and 165(1) of the Constitution respectively).

53 Secs 41(1)(f) \& (g) of the Constitution, 1996.

54 Ngcobo (n 49 above) 106.

5520013 SA 382 (CC).

56 Dodo (n 54 above) para 16.1. 
Ngcobo CJ refers to an 'appropriate doctrine of separation of powers' which acknowledges the operation of a symbiotic relationship between the role of the Constitutional Court and the other branches of government. ${ }^{57}$ In fact, a constitutional obligation is placed on the Court to decide matters where a branch of government has exceeded the bounds of the exercise of authority vested therein by the Constitution. ${ }^{58}$ Increasingly, the executive (and by extension the governing party, the African National Congress) has expressed concern over 'judicial overreach' in matters which are patently of a political nature. ${ }^{59}$ In his critique of Klare, Roux suggests that the 'politically engaged and politically transparent method of constitutional interpretation' 60 that accompanies the ideological project of transformative constitutionalism, is the only feature which distinguishes it from traditional interpretive methods otherwise employed by so-called 'liberal legalists. ${ }^{.61}$

Transformative constitutionalism departs from this school of thought by offering a post-liberal interpretation of the Constitution (post-liberal insofar as it proposes a 'politically loaded' method of transformative adjudication). ${ }^{62}$ The question which must be asked here is whether a transformative approach to adjudication does not inherently require a politicised discourse, especially in the realm of socio-economic rights, for example. In his analysis, Klare has found that 'the Constitution suggests not only the desirability, but the legal necessity, of a transformative conception of adjudicative process and method. ${ }^{\prime 63}$ Although the purging of legal reasoning and legal culture entrenched by apartheid policies is required, it is inadequate to pass new legislation to supplant apartheid-era laws without a material shift towards transformative adjudicative methods. Substantive legal reasoning, as a function of transformative constitutionalism, obliges judicial officers to openly engage in an evaluation of 'policy objectives or policy considerations' which inform the outcomes of their decisions. ${ }^{64}$ Legal outcomes should always find their basis in the purpose of prevailing principles and not in the mechanical operation of existing legal knowledge. Common law, indigenous law and case law should be relied on as interpretive guides. Over and above that,

57 Ngcobo (n 49 above) 40.

58 As above.

59 Ngcobo (n 49 above) 208.

60 T Roux 'Transformative constitutionalism and the best interpretation of the South African Constitution: Distinction without a difference?' (2009) 2 Stellenbosch Law Review 258266.

61 Ngcobo (n 59 above) 265.

62 Roux proposes that the insistence on a list of essential features which Klare identifies as characterising a postliberal Constitution is 'uncontroversial'. He contends that what should be understood from this label is an acknowledgment of a reading which is 'mandated by the text of the Constitution' itself.

63 Klare (n 4 above) 156.

64 G Quinot 'Substantive reasoning in administrative-law adjudication' (2010) 3 Constitutional Court Review 113. 
all relevant factors (especially extra-legal factors) ought to be considered in the framing of legal problems and must direct the rational means through which a solution may be reached.

The Constitutional Court should take a leading role in advancing widespread transformation. Of course, there are other mechanisms in place to deal with violations of fundamental rights. Chapter 9 of the Constitution establishes several institutions which exist in support of constitutional democracy. ${ }^{65}$ These institutions are required to respond to allegations of unfair discrimination, and to give an account of the pace and scale at which various state policies are being implemented. Pointedly, section 184 of the Constitution places an obligation on the South African Human Rights Commission (SAHRC) to ensure that measures taken by government to advance the realisation of socio-economic rights are evaluated on an annual basis. This leads to an argument for 'constitutional dialogue' between organs of state, which are jointly bound to 'respect, protect, promote and fulfil the rights in the Bill of Rights.' 66

\subsection{Constitutional dialogue between state institutions}

Langa CJ bemoaned the insurmountable task which has been placed at the feet of judges and legal practitioners. It is simply unrealistic for the burden of transformation to be solely placed in the hands of the judiciary. The executive branch creates policy, which ought to guide the process of large-scale social change. Efficient government processes are required to ensure the seamless implementation of transformative policies. However, we know that this is often not the case. In these instances, the legislature should be required to flex its own constitutional muscle by fulfilling its oversight role and demanding accountability for the popular mandate given to the executive. The legislature also has sole law-making powers and as such, should also play its role by debating and reflecting on mechanisms which can strengthen our constitutional democracy.

The Constitutional Court struck a balance in dealing with the procurement of a service provider for the disbursement of social assistance to grant recipients. ${ }^{67}$ This matter is significant for several reasons. Section 27 of the Constitution explicitly provides for the need to address the plight of previously disadvantaged groups and mandates the provision of access to basic services such as healthcare, food, water and pertinently, social assistance to those people who are unable to support themselves. Furthermore, the Social Assistance Act

65 S Liebenberg Socio-economic rights: Adjudication under a transformative Constitution (2010) 37.

66 Secs 7(2) and 8(1) of the Constitution.

67 [2017] ZACC 8 ['Black Sash']; 20141 SA 604 (CC) ['Allpay 1']; 20144 SA 179 (CC) ['AllPay 2']. 
establishes the circumstances under which social assistance may be given to groups who are eligible as contemplated in the provisions of this Act. ${ }^{68}$ Currently, many people in South Africa continue to suffer from rampant poverty as a result of various social ills including living in conditions of squalor, the widening income inequality gap and the stark increase in unemployment. Consequentially, millions of people now rely on the social grants which they receive from the South African Social Security Agency (SASSA). ${ }^{69}$

In Allpay 1, leave to appeal had been sought by AllPay Consolidated Investment Holdings (Pty) Ltd (Allpay) in relation to irregularities in the awarding of a tender for the provision of social grants to all nine provinces. ${ }^{70}$ Allpay had been unsuccessful in its bid for the tender and were seeking an order setting the contract aside. The Constitutional Court (the Court) dealt with a string of procedural issues relating to the process which was followed in bringing this review application, ${ }^{71}$ but for purposes of this discussion, focus will fall squarely on one central issue: the black economic empowerment (BEE) component (or lack thereof) of the winning bidder Cash Paymaster Services (Pty) Ltd (CPS).

CPS claimed, as a result of the requirements of the tender bid, that their BEE partners would manage $75 \%$ of the projects which would be embarked on in the contract. ${ }^{72}$ The Supreme Court of Appeal had maintained that the SASSA was not obliged to test the veracity of the claim made by CPS, which this Court found to be incorrect on the basis that BEE 'generally requires substantive participation in the management and running of any enterprise. ${ }^{, 73}$ The Court held that the legislative procurement framework specifically champions the need for economic redress for previously disadvantaged persons, ${ }^{74}$ and makes provision for state organs such as the SASSA to make determinations on a 'preferential procurement policy. ${ }^{75}$ The Broad-Based Black Economic Empowerment Act $^{76}$ centres itself on the empowerment of black people through the promotion of skills development and the endorsement of black management and control of companies that provide services to the state. ${ }^{77}$ As a result, the SASSA was under an obligation in terms of the Empowerment Act to 'ensure that the empowerment credentials of the prospective tenderers were investigated and confirmed before

68 Ch 2 of Act 13 of 2004.

69 In terms of section 2(2) of the Social Assistance Act 13 of 2004, SASSA is the body responsible for the provision of social assistance.

70 Allpay 1 (n 67 above) para 2.

71 Allpay 1 (n 67 above) para 15.

72 Allpay 1 (n 67 above) para 21.

73 Allpay 1 (n 67 above) para 22(e).

74 Allpay 1 (n 67 above) para 47.

75 Allpay 1 (n 67 above) para 48.

76 Act 53 of 2003 ('the Empowerment Act').

77 Allpay 1 (n 67 above) para 50. 
the award was finally made. That obligation became even more crucial when there were no other competitors left in the second stage. ${ }^{78}$ The Court held that the failure of the SASSA to investigate the empowerment credentials of CPS, despite the constitutional importance of substantive empowerment was fatally flawed. ${ }^{79}$ In light of the evidence led before the Court, the leave to appeal was upheld and the contract was set aside. However, in consideration of the devastating consequences that disruptions in the provision of grants would have, the Court opted to suspend the declaration of invalidity 'pending determination of a just and equitable remedy.' 80

In a separate matter (Allpay 2), the Court set out to deal with the appropriate remedy following the judgment on the merits. ${ }^{81}$ In considering whether a new tender process should be started, the Court was careful to contemplate whether initiating a fresh tender process would be more onerous on the public purse than upholding the existing (though constitutionally invalid) contract. ${ }^{82}$ The relevant factors to be considered which were advanced by the Centre for Child Law (Amicus Curiae) are persuasive for many reasons. Of paramount importance is protecting the: ${ }^{83}$

interest of beneficiaries in the uninterrupted payment of social grants, especially that of children; [the] cost to the public purse versus the proper use of public funds; and [the] need to promote respect for the rule of law, including both the value of deterrence and the maintenance of and respect for a fair and lawful procurement system.

After hearing submissions from the SASSA indicating that the agency intended to take over the provision of social grants by April 2017, ${ }^{84}$ and that in the meantime it would be too costly to undergo the process of awarding a new tender, the Court held that if a new tender is not awarded as stipulated in its order then the current contract would be allowed to run its course until 31 March 2017. The Court did not give this order lightly, taking cognisance of its obligation in terms of section 172(1)(a) to limit the extent of this inconsistency and treading carefully so as not to violate the separation of powers. ${ }^{85}$

The concluding matter is the ongoing failure by the SASSA to secure an internal grants distribution system, thereby placing the livelihoods of millions of people at risk. In the third related matter (Black Sash), ${ }^{86}$ the Court deals with the failure by the SASSA (and on a grander scale by the political office bearer responsible for 
oversight, the Minister of Social Development) to order a new tender process or to take over the grants payments system itself as directed in the remedial order (Allpay 2). ${ }^{87}$ This judgment is extremely important for purposes of this discussion because it demonstrates the gravitas of the constitutional powers vested in the Constitutional Court to make orders which bind other organs of state. As the guardian of the Constitution, ${ }^{88}$ the Court is sometimes required to broaden the boundaries of its discretionary powers (in close proximity to the violation of separation of powers) in order to uphold the spirit and purport of the Bill of Rights. In this case, the Constitutional Court is very careful to ensure that the right (as provided in section 27(1) of the Constitution) of millions of people to social assistance is not infringed. The Court makes the following decisive orders, amongst others: ${ }^{89}$

- 'It is declared that the SASSA and CPS are under a constitutional obligation to ensure payment of social grants to grant beneficiaries from 1 April 2017 until an entity other than CPS is able to do so and that a failure to do so will infringe upon grant beneficiaries' rights of access to social assistance under section 27(1)(c) of the Constitution.'

- 'The declaration of invalidity of the contract is further suspended for [a] 12-month period ...'

- 'The Minister is called upon to show cause on affidavit on or before Friday 31 March 2017 why -

- $\quad$ she should not be joined in her personal capacity; and

- $\quad$ she should not pay costs of the application from her own pocket.

The abovementioned orders are important to discuss for several reasons. The first reason is that CPS is placed under a constitutional obligation to ensure the continued payment of social grants until an entity other than CPS is able to perform its functions. The basis of this claim lies in the determination of the Court that CPS is an organ of state by way of the function it performs of ensuring the payment of social grants (a function which is public in nature). ${ }^{90}$ The Court is empowered to make this order to facilitate the continued and uninterrupted payment of social grants to grant recipients. Secondly, a further extension of the earlier invalidated contract is contentious. Madlanga $J$ proposes that as a necessary consequence, the constitutional obligation placed on CPS to ensure continued payments to grant recipients nullifies the earlier declaration of invalidity. ${ }^{91}$ As such, arising out of this order is a valid and binding contract between

87 Black Sash (n 67 above) para 3.

88 H Klug 'Finding the Constitutional Court's place in South Africa's democracy: The interaction of principle and institutional pragmatism in the Court's decision making' (2010) 3 Constitutional Court Review 1.

89 Black Sash (n 67 above) para 76.

90 Allpay 2 (n 67 above) para 52.

91 Black Sash (n 67 above) paras 79 \& 80. 
the SASSA and CPS (until such a time that an entity other than CPS is able to take over the grants payment system). Thirdly, Froneman J holds that arising out of her powers to appoint the CEO of the SASSA as well as her accountability to Parliament, the Minister of Social Development is ultimately responsible for the payments crisis and must therefore show cause why she should not be held personally liable for costs. ${ }^{92}$ Such an order has never been made and suggests that the Court takes very seriously the role of the executive in fulfilling its duties, especially in matters affecting the most vulnerable population groups. Although not expressly stated by the Court, it is curious that the parliamentary committee responsible for Social Development failed in its oversight role over the department.

The abovementioned orders given by the Constitutional Court illustrate a self-awareness of the immense responsibility placed on the Court to ensure that over 15 million South Africans receive the necessary social assistance which they require. It is evident that the Court may be required to deliver judgments which strike a balance between 'principled argument and institutional pragmatism'. ${ }^{93}$ This measured approach should be celebrated because it creates space for reflection on the dynamic and engaged role which the Court plays in postcolonial South Africa. The tension which exists between 'the internal [traditional patterns of legal argumentation] and external [pragmatic and executive-minded] dimensions of the Court's role as guardian of the Constitution' permits the court to develop a jurisprudence of its own. The convergence of these opposing dimensions in turn allows the Court to engage in a highly politicised discourse without much legal restraint, in order to safeguard the rule of law. ${ }^{94}$ The existence of constitutional dialogue between state institutions is vital to ensuring that the Constitutional Court does not continue to bear sole responsibility for the development of substantive reasoning in rights discourse, as well as in the widespread transformation of our social and political institutions.

\section{The influence of Ubuntu on constitutionalism}

In its first ruling, the Constitutional Court was delegated the prerogative of deciding on the constitutionality of capital punishment as a valid sentencing option. ${ }^{95}$ However, this matter dealt with more than just a question of the interpretation of the right to life, protected under section 11 of the Constitution. This matter was of great importance in developing the 'value-based jurisprudence' which continues to inform legal reasoning and adjudicative methods 
used today. ${ }^{96}$ A key question is how to move towards an African jurisprudence that takes up a dignified identity and is given the necessary credence in law? The main problem which sits at the heart of the colonial project is the epistemicide that ensued. As a result, communal values were replaced by individual freedoms, morality was replaced by law and reconciliation was replaced by retribution. ${ }^{97}$ This began the impoverishment of moral and ethical considerations in law, and by operation throughout social, political and economic institutions.

In the early nineteenth-century, English law started making a transition to positivism which saw these ideals being transplanted to the South African legal system. ${ }^{98}$ This inadvertently had a devastating effect on indigenous African systems of law, which continue to enjoy subordinate status in modern South African law. Fast-forward to the present day and the intrinsic demand for justice (entailing the restoration of the dignity of the indigenous African people) has still not been addressed. ${ }^{99}$ Restitution and reparations ought to have followed immediately after the achievement of democracy, ${ }^{100}$ but this was not the case. In the process of securing political rights (such as the right of franchise and the right to freedom of association) ${ }^{101}$ for all people, especially for the indigenous African population, the state failed to prioritise important projects such as the acceleration of land reform, land tenure reform and the redistribution of land, ${ }^{102}$ as well as other mechanisms to address the class and racial divide which still persists. Adopting an Ubuntu understanding of law in existing social and economic institutions is essential in dealing with the prevailing effects of colonisation, apartheid and racism. ${ }^{103^{3}}$

\subsection{Ubuntu: Collective self-determination}

It can be no coincidence that in his description of a post-liberal reading, Klare refers to the Constitution as embracing 'a vision of collective self-determination. ${ }^{104}$ Not only is collective selfdetermination invoked as a vision to be aspired towards, but this right is further entrenched in section 235 of the Constitution. This vision of law aligns with and closely resembles the core belief at the heart of

96 Quinot (n 63 above) 111.

97 W Le Roux 'Natural law theories' in C Roederer and D Moellendorf (eds) Jurisprudence (2004) 40.

98 J Dugard 'The judicial process, positivism and civil liberty' (1971) 88 South African Law Journal 184.

99 MB Ramose 'An African perspective on justice and race' Polylog Themes/Focus https: / / them.polylog.org/3/frm-en.htm (accessed 15 March 2017).

100 Ramose (n 99 above) 2.

101 Secs 19(3)(a) and 18 of the Constitution, 1996.

102 Secs 25(5), (6) \& (7) of the Constitution, 1996.

103 Ramose (n 99 above) 4.

104 Klare (n 4 above) 153. 
the philosophy of Ubuntu. Klare further asserts that unlike other bills of rights which are rooted in classic liberal tradition, 'the South African Constitution embodies the idea that the power of the community can (and must) be deployed to achieve goals consistent with freedom, that collective power can be tapped to create social circumstances that will nurture and encourage people's capacity for self-determination. ${ }^{105}$ In his doctoral thesis, ${ }^{106}$ Prof Ndima takes a similar line in his characterisation of pre-colonial African tradition. The indigenous African traditions of the time evince the acceptance of a worldview informed by 'a shared communal life, a sense of common belonging, collective ownership of assets, and group solidarity - all of which combined to foster a distinctly African concept of justice, law and human rights. ${ }^{107}$ In this characterisation, Ndima advances the idea that these values held so much significance within this social system, that tenets of indigenous religion and culture seemed to form the source of acceptable human conduct. ${ }^{108}$

Ubuntu is a very specific philosophical concept which is encompassed by the word 'Botho' in my own native tongue of Setswana. However, I will lean on the isizulu expression of the word as it is more descriptive in its formulation and etymological origins. Ubuntu comprises two words, the prefix ' $u b u$ ' and the root ' $n t u$ '. ${ }^{109}$ These two words are inseparable as they jointly designate a oneness as well as an indivisible wholeness. ${ }^{110}$ Ubuntu law as we know it responds to the lived experiences of indigenous African people and necessarily never reaches finality until harmony has been realised. ${ }^{111}$ In keeping with African beliefs, justice is deemed to be immutable irrespective of changing circumstances and as such, cannot be undone by prescription or the passage of time. ${ }^{112}$ Conversely, in pursuit of restoration and transformation, Ubuntu should function as a barometer by which the validity of law and justice must be measured. ${ }^{113}$ More than just an African philosophical ideal, it embodies values which ascribe ethical considerations for the fulfilment of common societal goals.

105 As above.

106 DD Ndima 'Re-imagining and re-interpreting African jurisprudence under the South African Constitution,' unpublished PhD thesis, University of South Africa, 2013.

107 Ndima (n 106 above) 2.

108 As above.

109 Ramose (n 99 above) 2.

110 As above.

111 Ramose (n 99 above) 3.

112 As above.

113 Ramose (n 99 above) 1. 


\subsection{The pursuit for restorative justice}

When the negotiated settlement was reached in the events leading up to the attainment of constitutional democracy, two conditions were being sought: decolonisation as well as democratisation. ${ }^{114}$ Decolonisation had to do with reclaiming the title to land and dominion over that land, ${ }^{115}$ which under normal circumstances would require colonisers to renounce their claim to territory. The inclusion of a property clause in the Constitution (which calls for the expropriation of land subject to the provision of just and equitable compensation $)^{116}$ protected the ownership rights of existing property owners and in so doing compromised the ability of the state to reclaim the title to land. Democratisation on the other hand, was concerned with bestowing entitlements to the once-excluded indigenous African people which they previously did not enjoy. So whilst the advent of a new Constitution might have brought democracy, the question of title to land still remains to this day. Throughout the liberation struggle, the language used by political activists at the time pivoted on the fight for freedom and not on the pursuit of democracy. Previously disadvantaged groups understood the objective to be socio-economic and political emancipation. It is difficult to argue that this has been achieved when black people remain the face of poverty. A contradiction existed between the compromises reached between political representatives and the justice sought by ordinary citizens. ${ }^{117}$ In recent times, there has been public outcry about the framing of language used at the time and how this distorted the meaning of what ordinary people understood to be the common objective. The Sotho proverb molato ga o bole is relevant here as it holds the belief that justice does not and cannot prescribe through the mere passage of time. As a result, the restoration of title to territory is an immutable consequence which must still be attended to even as things stand right now. In light of this deliberate oversight, ${ }^{118}$ democratisation in this context has had little success to restore sovereignty unencumbered to the precise quantum by which it was taken at conquest.

Sibanda conceives constitutionalism and the intention thereof to limit the powers of the state to the confines of a written text. ${ }^{119}$ In his engagement with this discourse, Sibanda concedes that there

114 Ramose (n 99 above) 5.

115 Ramose (n 99 above) 7.

116 Secs 25(1), (2) \& (3) of the Constitution, 1996.

117 Ramose (n 99 above) 7.

118 On the face of it, 'deliberate oversight' could present as a paradox but it is my belief that the parties present at the negotiations of the early 1990s were aware of this need to restore title to territory but acknowledged (consciously or otherwise) that this would be highly contentious among existing property owners and could potentially impede the negotiations for a democratic settlement. 
seems to be very little evidence of scholarly interrogation into the correspondence between constitutionalism and the national project to eradicate poverty. ${ }^{120}$ In excavating the role of constitutionalism to bring about the eradication of poverty, regard must be given to the question whether constitutionalism should even pivot on social transformation. ${ }^{121}$ Sibanda proposes two approaches which are useful in the conception of liberalism, an 'orthodox or liberal democratic approach' and a 'transformative approach. ${ }^{122}$ Proponents of the first approach might accord credence to a peaceful transition of power which derives legitimacy from the existence of 'regular free and fair elections', a 'representative democracy' and an 'independent judiciary' with constitutional powers of review and the upholding of the rule of law. ${ }^{123}$ Proponents of the second approach recognise that even with the 'inclusion of socio-economic rights in the Bill of Rights' and a focus on the improvement of the lives of all South Africans, most black South Africans remain subject to rampant poverty. ${ }^{124}$ Worse still, the effects of apartheid such as income inequality and spatial geography only serve to deepen existing levels of poverty.

\subsection{The 'land question'}

Sibanda is partially correct in his view which recognises that transformative constitutionalism might not be capable (in and of itself) of driving social transformation with any more expediency to cultivate true political and economic agency. ${ }^{125}$ Several limitations are inherently present in the preservation of a liberal democratic tradition which does not cogently translate to the eradication of poverty. ${ }^{126}$ The provision of basic resources such as water, food, housing and education ought to be integral to the project of restorative justice. Although these interventions have already been implemented by the state, significantly more people are dependent on the state for social assistance today than at any other time since the adoption of the Constitution. More is required in the form of political will (or possibly something else) to put into motion an aggressive socialist programme which aims not only to provide basic resources to previously disadvantaged groups, but also imparts vital skills to curtail prolonged dependence on the state.

119 S Sibanda 'Not purpose-made! Transformative constitutionalism, postindependence constitutionalism and the struggle to eradicate poverty' (2011) 22 Stellenbosch Law Review 482.

120 As above.

121 Sibanda (n 121 above) 483.

122 Sibanda (n 121 above) 484.

123 As above.

124 Sibanda (n 121 above) 485.

125 Sibanda (n 121 above) 486.

126 Sibanda (n 121 above) 498. 
In reflection, the enactment of the Promotion of National Unity and Reconciliation $\mathrm{Act}^{127}$ was a clear foray into unearthing the unspeakable wrongs of the past with a focus on restorative justice. However, the framing and wording of this Act (which established the Truth and Reconciliation Commission) places a heavy emphasis on the granting of amnesty to those persons who tender truthfulness for rights violations committed during apartheid. Under the prescripts of indigenous African law, justice and restoration are incompatible with amnesty because the perpetrator loses nothing of their own. The descriptive point here is that even this measly attempt towards restorative justice is of itself a flawed process because perpetrators of racially motivated crimes lose nothing. Evidently, the state does not fully grasp the tenets of restorative justice. To even attempt to address the land question seems unfathomable in this context

The point of departure would be to establish an African conception of property or property rights. The key characteristic of indigenous African law (as derived from the philosophy of Ubuntu) is communal life. Property rights function in much the same way. Individuals only lay exclusive claim to personal use items such as clothes, letters and other items which are not of direct interest to the other members of the group. ${ }^{128}$ However, 'communal ownership [is] applied in respect of major assets such as land, livestock, [and] farming implements ...,129 Items are expressed 'using inclusive language, ${ }^{130}$ therefore, even on a literary level there seems to be a disjuncture between the Roman-Dutch common law and indigenous African law. This perhaps informs the phenomenon of matyotyombe (in isiXhosa) or baipei (in the Sotho languages). The phenomenon of matyotyombe is a manifestation of the failure of political leadership to deliver the unencumbered tenure of land. ${ }^{131}$ Matyotyombe are squatters who are forced to occupy conditions of filth, extreme poverty and human degradation. ${ }^{132}$ Matyotyombe penetrate and affix themselves on vacant land, be it private property or not. ${ }^{133}$ The reason for this might be more obvious when adopting baipei. The Sotho term is more descriptive because it denotes a people who have affixed themselves to a particular place and are not confined to demarcated space. ${ }^{134}$ This unearths the assertion by baipei of their perceived right to the occupation of any vacant land. To prevent a crisis, the state must expedite land reform and scrutinise the current land reform programme. Ndima asserts that African law ought to be

127 Act 34 of 1995.

128 Ndima (n 106 above) 81.

129 As above.

130 Ndima (n 106 above) 82.

131 Ramose (n 99 above) 8.

132 As above.

133 As above.

134 As above. 
implemented 'within its own life-world' and that when 'Western normative standards' are construed upon it, ${ }^{135}$ immense distortion takes place. Unfortunately, the flexibility for which African jurisprudence is known has been lost to the rigidity imbued upon it 'by changing the system's texture and complexion to suit Western standards of justice and morality. ${ }^{136}$ As such, it would be futile to advocate for the recognition of constitutional status equal to that of the Roman-Dutch common law.

\section{Conclusion}

In reflection, transformative constitutionalism is a system of constitutional enactment which is revered for its key feature of transformation, and which places the achievement of equality in social and political institutions at the fore. In re-imagining what a truly equal society could look like, transformative constitutionalism is instructive to foster a culture of reconciliation and substantive reasoning, and to root out a culture of authoritarianism. So where will the South African be in the future? Klare cautions against a tendency of participants in a specified legal culture to 'reach consensus' on a 'narrow range of outcomes' which are constrained in the text of the legal materials before them. ${ }^{137}$ Judges and legal actors should reflect more deliberately on what constitutes persuasive legal argument and should actively pursue their 'interpretive creativity' to promote the 'democratic and egalitarian values enshrined in the Constitution.'138

On the question of a formal versus a substantive vision of law, one can hardly exist to the exclusion of the other. However, insistence on a formal vision of law merely conceals one's 'substantive reasoning and choices. ${ }^{139}$ This circular logic generates a warped sense of reality in which the authority for the existence of a legal rule is derived from the substance of the rule itself. ${ }^{140}$ Klare emphasises that 'no neutral decision procedures exist capable of [...] definitively establishing' what constitutes an objective interpretation of a particular text. ${ }^{141}$ As a result, judges imbue legal materials with 'value-laden meanings' informed by their own political and moral convictions. ${ }^{142}$ By his own account, Klare concedes that a 'progressive legal culture' alone is insufficient to assure the success of the transformative enactment of our Constitution. ${ }^{143}$ In my opinion, employing a politically engaged

135 Ndima (n 106 above) 121.

136 Ndima (n 106 above) 120.

137 Klare (n 4 above) 160.

138 Klare (n 4 above) 171.

139 Froneman (n 33 above) 5.

140 Froneman (n 33 above) 7.

141 Klare (n 4 above) 160.

142 Klare (n 4 above) 163.

143 Klare (n 4 above) 170. 
method of adjudication yields honesty about one's policy choices and promotes transparency. In this regard, it is helpful to leverage interaction with other branches to facilitate dialogue between the judiciary, the legislature and the executive which must collectively uphold the Constitution.

Ndima bemoans the perversion of the 'conception of law that presents Western jurisprudence as synonymous with law.' ${ }^{144}$ Law is not self-generating. In this sense, judges and legal practitioners are therefore complicit in applying Eurocentric legal sensibilities to African legal problems. ${ }^{145}$ What is evident is the need to find the place of Ubuntu in our constitutional discourse once again. If not in the form of justiciable principles, then at least as an interpretive tool to advance 'ethically sound interpretations of difficult [constitutional] clauses' which cannot be solved by 'traditional liberal jurisprudence." 146 Finally, the 'collective unity, group solidarity and conformity' of Ubuntu can be harnessed to 'promote new patriotism' integral to a renewed transformative jurisprudence. ${ }^{147}$

144 Ndima (n 106 above) 103.

145 Ndima (n 106 above) 103.

146 Cornell \& Van Marle (n 29 above) 220.

147 Y Mokgoro 'uBuntu and the Law in South Africa' in Cornell D and Mavangua N (eds) Ubuntu and the law: African ideals and post-apartheid jurisprudence (2012) 318. 